\title{
Importance of Family Medicine Clinic in COVID-19 Pandemic
}

\author{
(D) Hatice Rumeysa Selvi, (D) Seçil Arıca \\ University of Health Sciences Turkey, Prof. Dr. Cemil Taşçığlu City Hospital, Clinic of Family Practice, Istanbul, Turkey
}

\section{Abstract}

Pandemics are global events that have always existed in the history of the world and that can cause profound changes. The Severe Acute Respiratory syndrome-coronavirus-2 pandemic, which appeared in China in December 2019, was also a current pandemic that affected life all over the world and in our country. Like many countries, Turkey has directed its existing strong health system to fight this pandemic. Family physicians who are the first to encounter pandemics have taken an important place in this fight by taking part in every step of the work to combat the Coronavirus Disease-2019 (COVID-19) pandemic. In this study, it was aimed to examine the duties and responsibilities of Okmeydani Family Medicine Clinic in COVID-19 pandemic both in the 1 st and $3^{\text {rd }}$ step health care.

Keywords: COVID-19, family physicians, pandemic,

\section{INTRODUCTION}

Coronavirus Disease-2019 (COVID-19), which has created a widespread pandemic worldwide since December 2019 and which we are still struggling with in our country, continues to seriously threaten life.

Pandemic means "affecting all people" consisting of the words "pan" meaning "all" and "demos" meaning "people" in the Ancient Greek language. Considering the history of the pandemic, it is seen that 21 pandemics have occurred that have affected humanity so far. Endemics and pandemics, which cause unforgettable pain and death in humans and animals, have deeply affected health, psychology and life in every age, leading to the collapse of states and large social migrations. Although infectious diseases have always existed in the world throughout human history, the increasing human mobility and the ease of interaction with different human and animal populations across continents have facilitated the formation and spread of pandemics. Plague, cholera, influenza, AIDS and now COVID-19 are among the pandemics that have resulted in the death of a large number of people and affect the world the most $(1,2)$.
Today, accepting an outbreak as a pandemic depends on the approval and acceptance of the World Health Organization (WHO). According to WHO, for an infection to be a pandemic, it must meet the following three conditions:

1- The emergence of a previously unknown outbreak.

2- Disease agent infecting people and causing a dangerous disease.

3- Easily and continuously spreading of the cause of the disease (1).

In December 2019, a large number of patients with pneumonia of unknown cause were reported in a seafood market in Wuhan, China's Hubei province. The WHO first announced that the reason for these complaints was a new type of coronavirus (2019-nCoV) on January 12, 2020, and on February 11, 2020, this new virus was named Severe Acute Respiratory syndromecoronavirus-2. The WHO named this pandemic as the "COVID-19" pandemic on March 11, 2020. According to the WHO, there have been 4,735,622 patients diagnosed and 316,289 deaths as of 20.05.2020 (1,3,4).

Phone: +90 5054542405 E-mail: drsecilarica@gmail.com ORCID ID: orcid.org/0000-0003-0135-6909

Cite this article as: Selvi HR, Arıca S. Importance of Family Medicine Clinic in COVID-19 Pandemic.

Eur Arch Med Res 2020;36(Suppl 1):65-7

- Copyright 2020 by the University of Health Sciences Turkey, Prof. Dr. Cemil Taş̧̧ığlu City Hospital

European Archives of Medical Research published by Galenos Publishing House. 
Turkey is one of the earliest countries in the world to take measures regarding COVID-19. The Scientific Committee was established by the Ministry of Health on January 10 . Various administrative measures were taken in line with the recommendations of the Scientific Committee, and the updated diagnosis and treatment guideline of COVID-19 was created by the board according to the developments. Elective examinations, procedures and surgeries were postponed. It was recommended that non-urgent patients receive service from their family physicians first. The first patient was detected in Turkey on 10.03.2020 $(3,5)$. Since then, measures have been increased across the country to prevent and reduce the spread of the virus in the society. Measures for the source of the disease have been taken and continue to be taken in subjects such as finding the source, reporting the disease, definitive diagnosis, treatment of the patients, isolation, searching for carriers and following the patients with suspected COVID-19. Measures for the healthy persons have been taken and continue to be taken in subjects such as quarantine and observation.

Contact tracing is of great importance in protecting against COVID-19 in our country. In other words, screening the contact chain related to an infectious disease and/or finding the source of the disease and taking the measures before it spreads have an important place in the fight against the disease. At this point, the field work of the family physicians and district health directorates, who provide health services in the first step, constituting the contact tracing team, is of great importance. Screening people with whom they come into contact around patients with COVID-19 and diagnosing the disease in these people in the early period, giving treatment, following up and preventing the spread of the disease define the contact tracing (3).

Family medicine assistants working in 6 units of EducationFamily Health Centers (E-FHC) affiliated to the family medicine clinic of our hospital have also been a part of contact tracing in this process. People with a positive polymerase chain reaction (PCR) test fall on the Public Health Management System screen of their family physician. After this point, the patients are called and the people they are in contact with are identified and screened one by one. While the PCR sample is taken from the symptomatic contacts, the family physicians call the asymptomatic contacts every day to ask whether they have symptoms and if they develop symptoms, they are referred to the relevant hospital by referring to 112 , and this process and follow-up are meticulously continued for 14 days. Contacts with a positive PCR result and with good general condition are treated at home in the early period and are followed up by their family physicians for 14 days at weekends and weekdays in terms of symptoms and drug use. Isolation training of patients and contacts at home and follow up of isolation are managed by family physicians. In this process, approximately 250 patients have been followed up in our E-FHCs with the method of contact tracing, and preventive medicine, one of the main duties of family medicine, has been performed by providing isolation training. Considering that the most effective and fastest solution against the COVID-19 pandemic is social isolation, which is an anti-infectious activity, as in all infectious diseases, the key importance of family physicians who provide primary health care services to follow up and inform them is once again understood.

While all these continue, normal outpatient clinic services continue at E-FHC for emergency and non-postponable situations. At this point, the triage system application has been initiated. Contacts with a COVID-19 positive patient, who have symptoms (such as fever, cough, etc.) are identified, the detected patients are immediately put on a mask and isolated, and the district health directorates are notified and the patient is brought to the nearest COVID-19 outpatient clinic. In addition, people who are monitorized due to pregnancy or having adolescents, infants or children have been called and appointments have been made at intermittent hours, thus reducing the number of outpatient clinic volume and contact. In order not to increase the risk against other infections while protecting the society from a source of infection, childhood vaccinations have been administered without delay, and babies who could not be reached for vaccination have been vaccinated by home visits. See Table 1 for the status of other outpatient clinic services (6).

In this process, the number of nine Family Medicine Outpatient Clinics within the Family Medicine Clinic of Prof. Dr. Cemil Taşcıoğlu City Hospital has been reduced to three. As Family Medicine and adult vaccine outpatient clinic, we have continued to serve in the institution. By closing smoking cessation outpatient clinics and other family medicine outpatient clinics, we have been clinically involved in the fight against the COVID-19 pandemic. Family medicine clinic specialists and residents have been involved in 24-hour quarantine duties since the first day of the quarantine services opened in our hospital on 20 March 2020. As of March 24, 2020, all other branch residents have been included in these duties. In the beginning, 2 family medicine specialists and 40 family medicine residents were on duty at regular intervals, while this number reached 55 resident physicians with the new starters. During the duties, 1 family 


\begin{tabular}{|l|l|}
\hline \multicolumn{2}{|l|}{ Table 1. Status of Education-Family Health Centers outpatient clinic services } \\
\hline The reason for the patient's arrival at E-FHC & Management of health care services implemented in E-FHC \\
\hline Prescripting medicine with report & Directed to the pharmacy in accordance with the Ministry of Health circular \\
\hline $\begin{array}{l}\text { To be examined } \\
\text { Getting a marriage/military report } \\
\text { To get mental report for use in notary and deed transactions } \\
\text { Get vaccinated }\end{array}$ & The individual is directed family physician to whom he/she is registered \\
\hline $\begin{array}{l}\text { Getting a driver report } \\
\text { To have a laboratory examination } \\
\text { Getting screened for cancer }\end{array}$ & Temporarily postponed except in compulsory cases \\
\hline Follow-up of babies, children, adolescents and pregnant women & $\begin{array}{l}\text { The individual is directed to the family physician to whom he/she is } \\
\text { registered, if the appointment day and time are suitable }\end{array}$ \\
\hline E-FHC: Education-Family Health Centers & \\
\hline
\end{tabular}

medicine resident has been responsible from 1 ward and follows up an average of 25 patients with COVID-19. Every day, 8 family medicine residents have been on duty in quarantine wards, one in the infectious diseases service. From the beginning until June 15 , approximately 490 duties were held by family medicine residents. During the duty; family medicine residents have had a one-to-one active role in the hospitalization of the patient from the emergency department, arranging the rooms, providing isolation, taking swab samples, requesting the examinations, planning and starting their treatments with the Infectious Diseases on-duty specialist, re-evaluating other chronic diseases, if any, and making the necessary consultations and in the process until discharge. By carefully following the symptoms and signs of the patients, they organize the referral of the patients whose general condition deteriorates to the intensive care unit. Resident and specialist physicians of the family medicine clinic evaluate family medicine in the best way as a specialty branch that can take a holistic approach and evaluate the human body, regardless of age, gender and disease, without separating human body according to its organs and systems. Rotations, which are also a part of family medicine residency training, have been stopped except for emergency room rotation in order to reduce the virus load and take an active role in combating the pandemic. The rotations of our family medicine residents in the Emergency Department have continued.

\section{CONCLUSION}

During this whole process, Prof. Dr. Cemil Taşçıŏlu City Hospital Family Medicine Clinic, both by tracing for isolation for the prevention of contamination in the contact tracing team in $\mathrm{E}-\mathrm{FHC}$ in primary care, and by being involved in the diagnosis, treatment and hospitalization process of patients with COVID-19 in the emergency service, outpatient clinic and quarantine services in the third step hospital has taken its place in the front lines in combating the pandemic.

\section{Ethics}

Peer-review: Externally and internally peer-reviewed.

\section{Authorship Contributions}

Surgical and Medical Practices: H.R.S., S.A., Concept: H.R.S., S.A., Design: H.R.S., S.A., Data Collection or Processing: H.R.S., S.A., Literature Search: H.R.S., S.A., Writing: H.R.S., S.A.

Conflict of Interest: No conflict of interest was declared by the authors.

Financial Disclosure: The authors declared that this study received no financial support.

\section{REFERENCES}

1. World Health Organization. Coronavirus disease (COVID-19) pandemic. Available from: URL: https://www.who.int/emergencies/diseases/novelcoronavirus-2019

2. Centers for disease control and prevention. Pandemic Influenza. Available from: URL: https://www.cdc.gov/flu/pandemic-resources/

3. COVID-19 Pandemi Değerlendirme Raporu; Türkiye Bilimler Akademisi (17 Nisan 2020). Available from: URL: http://www.tuba.gov.tr/files/ images/2020/kovidraporu/Covid-19\%20Raporu-Final+.pdf

4. T.C. Sağlık Bakanlığı. Covid-19 (Sars-Cov-2 Enfeksiyonu) Rehberi, Bilim Kurulu Çalıșması (13 Nisan 2020). Available from: URL: https://www.teb. org.tr/versions_latest/1240/13nisansbrehberi

5. TÜBITAK. Covid-19 Türkiye Web Portalı. Available from: URL: https:// covid19.tubitak.gov.tr/anasayfa

6. Türkiye Aile Hekimleri Uzmanlık Derneği (TAHUD). Aile sağlığı merkezlerinde Covid-19 yönetimi (1 Nisan 2020) Available from: URL: https://www.tahud.org.tr/news/view/asm-de-Covid-19-yönetimi\%28tahud-01-nisan-2020\%29 